\title{
Effects of sewage discharge, fishing pressure and habitat complexity on coral ecosystems and reef fishes in Hawaii
}

\author{
Richard W. Grigg \\ Department of Oceanography, University of Hawaii, Honolulu, Hawaii 96822, USA
}

\begin{abstract}
The major factor controlling the abundance of reef fishes in Hawaii (USA) appears to be habitat complexity (bottom topographic relief and interstitial space). Fishes aggregate in areas of high habitat complexity at biomass levels which, in areas protected from fishing, may significantly (by 2 to 5 times) exceed levels supported by primary production within the ecosystem. High relief natural areas 'act' like artificial reefs in terms of aggregating fishes. Reef fish abundance is also affected by fishing pressure in the main Hawaian Islands. Areas protected from fishing (Marine Life Conservation Districts, MLCDs) support standing crops of reef fishes that average about $45 \mathrm{~g} \mathrm{~m}^{-2}$ higher than areas open to fishing. In areas unprotected from fishing, reef fish abundance has significantly declined in recent years. Conservation and management of reef fishes would be improved if more high relief areas were protected from fishing. Thus far, 11 MLCDs have been established in such areas in Hawaii. The discharge of primary or secondary treated sewage effluent into the ocean in Hawaii through deep ocean outfalls causes no apparent negative environmental impact to coral reef ecosystems. Deep ocean outfalls in fact attract reef fishes. Increases in abundance around the outfalls appears to result from increased habitat complexity brought about by the construction of the pipelines and surrounding caprock and concrete. A small amount of the variability (increase) in reef fish abundance around the outfalls may also be due to food subsidies (particulate organic matter) in the effluent. No species of fish, coral, invertebrate or algae at the outfalls exhibited any pathological symptoms. Hence, statewide declines in reef fish abundance in areas unprotected from fishing are not related to the discharge of sewage effluents via deep ocean outfalls. Rather, these declines appear to have been caused by overfishing.
\end{abstract}

KEY WORDS: Fishery management $\cdot$ Pollution $\cdot$ Overfishing $\cdot$ Coral reefs

\section{INTRODUCTION}

In recent decades, nearshore fishery resources in Hawaii (USA) have undergone serious declines (Shomura 1987). Shomura compiled commercial landings data and anecdotal information over the last century and estimated that the magnitude of the decline was about 5 -fold in 1987 . Possible factors causal of this decline include (1) overfishing, (2) point source sewage disposal, (3) nompoint source pollution, (4) habitat destruction, and (5) natural fluctuation in recruitment and mortality of coastal species. Many fishermen consider overfishing to be the major cause (Harmon \& Kitekaru 1988). Nevertheless, a widespread perception held by the public and some environmentalists is that various sources of pollution are responsible. This view is frequently reinforced by the media in spite of research which shows otherwise (Russo et al. 1981, 1988, Russo 1982, Nelson et al. 1991). Controversy over the cause of declines in the fisheries is also due to lack of information and past research. Recognition of this problem prompted this study. The major goal was to measure the variability in reef fish abundance and coral community structure associated with point source pollution from deep ocean outfalls and fishing pressure in Hawaii.

Another objective of the study was to describe and compare the impact of primary and secondary treated sewage discharges on coral ecosystems in Hawaii and to determine whether any differences exist between 
the 2 levels of treatment. In the United States, a controversy has existed for about 20 yr over the environmental impact of primary versus secondary treated sewage on the marine environment (Sun 1989). In 1972 , the U.S. Congress passed the Clean Water Act. This bill required all municipalities in the U.S. that discharge waste into the nation's waterways to utilize secondary treatment. The Act was amended in 1977 to allow for waivers to secondary treatment (Section 301-h) in circumstances where it is not needed to protect the environment or public health. Each municipality in the United States must assess this question on a case-by-case basis.

\section{METHODS}

Twenty-three stations were selected for study. Areas were chosen to compare coral ecosystems exposed to point source pollution (treatment) from deep ocean outfalls with normal unexposed areas (controls) and areas protected from fishing (treatment; Marine Life Conservation Districts, MLCDs) with areas unprotected from fishing (controls). All control stations were selected so as to be as similar as possible to treatment stations in all environmental respects (except exposure to sewage and fishing). At each of these stations, data were collected on coral species, coral species cover, fish species, fish abundance and behavior, dominant benthic algae and invertebrates, depth, bottom topography (habitat complexity, see below), temperature, salinity, turbidity, thickness and aerial extent of bottom sediments, build-up or absence of particulate organic matter on the bottom, current speed and direction, wave height, wave direction and period and bottom surge. At the deep ocean outfall stations, data on water quality (nutrients: phosphate, nitrate, nitrite, ammonium) bacteria and chlorophyll a were also collected, however, the results of this part of the study are reported elsewhere (Parnell 1992).

The 3 ocean outfall stations selected for study are all on the island of Oahu. These included the outfalls in
Kailua Bay and off Sandy Beach, both of which discharge secondary treated sewage, and the outfall off Waianae, which discharges primary treated sewage (see Table 1 for other design characteristics). Secondary treatment removes about $85 \%$ of the biological oxygen demand (BOD) and suspended solids (SS) while primary treatment only removes about $30 \%$ of the BOD and SS.

Control stations for each ocean outfall were chosen on the basis of similarity in habitat and depth and were situated outside the area of influence of the outfall effluent plumes.

Data collection for all stations spanned a 24 mo period between June 1990 and May 1992. Data on corals and other benthos were collected using a phototransect method (Grigg \& Maragos 1974). Each transect consisted of a $50 \mathrm{~m}$ line previously marked at 10 random intervals that was placed along an isobath on the bottom. A $0.7 \mathrm{~m}^{2}$ quadrat was then placed over each random point and photographed. Photographs were later projected onto a grid in the laboratory where coral species abundance (cover) was recorded. These data were used to calculate coral species diversity and abundance.

Fish counts were taken at each station around and above the transect line encompassing an area $10 \mathrm{~m}$ on either side of the line, producing samples $1000 \mathrm{~m}^{2}$ in area $(50 \times 20 \mathrm{~m})$. Relative to other fish transecting methods (Russo 1982, Brock \& Norris 1989), $1000 \mathrm{~m}^{2}$ is a large sample area. While fish counts over this area require at least 45 min of underwater time to collect, large samples integrate small-scale patchiness (schools) and help reduce avoidance errors. Using this method, some fish may be counted twice but this source of error is small. Fish behavior was also observed and recorded because it is a useful methods of qualitatively gauging past spear-fishing effort in a given area.

The median length of each fish species on each transect was estimated visually and recorded. Fish length was converted to biomass using Ricker's equation for isometric growth, where $W=k l^{3}$ (Ricker 1975). Growth

Table 1. Design characteristics of ocean outfalls selected for study. mgd: million gallons per day

\begin{tabular}{|c|c|c|c|c|c|c|}
\hline Outfall & $\begin{array}{c}\text { Date } \\
\text { operational }\end{array}$ & Treatment & $\begin{array}{l}\text { Depth } \\
\text { (m) }\end{array}$ & $\begin{array}{l}\text { Discharge } \\
\text { rate, } 1991\end{array}$ & $\begin{array}{l}\text { Suspended } \\
\text { solids }\left(\mathrm{mg} \mathrm{l}^{-1}\right)\end{array}$ & $\begin{array}{c}\text { Distance } \\
\text { offshore }(\mathrm{km})\end{array}$ \\
\hline Kailua & 1977 & Secondary & 33 & $\begin{array}{c}10 \mathrm{mgd}^{-1} \\
0.44 \mathrm{~m}^{3} \mathrm{~s}^{-1}\end{array}$ & 30 & 1.61 \\
\hline Waianae & 1968 & Primary & 33 & $\begin{array}{l}2.5 \mathrm{mgd}^{-1} \\
0.11 \mathrm{~m}^{3} \mathrm{~s}^{-1}\end{array}$ & $>30$ & 1.30 \\
\hline Sandy Beach & 1961 & Secondary & $12-15$ & $\begin{array}{l}4.3 \mathrm{mgd} \\
0.19 \mathrm{~m}^{3} \mathrm{~s}^{-1}\end{array}$ & 30 & 0.40 \\
\hline
\end{tabular}


coefficients $(k)$ for each major species were obtained from the Hawaii Division of Aquatic Resources as reported by Evans (1974).

The abundance of coral reef fishes is known to be affected by bottom topography and interstitial space, i.e. habitat complexity (Gladfelter \& Gladfelter 1978, Anderson et al. 1981). For this reason, a measure of topographic relief or rugosity was developed. This was done by first laying a $50 \mathrm{~m}$ transect tape on the bottom so it conformed to all bottom irregularities such as holes, crevices and cavities. The tape was then pulled horizontally tight, to eliminate all the slack produced by the relief. The resultant ratio of horizontal distance to $50 \mathrm{~m}$ (crevice to platform) was used as a relative measure of habitat complexity. Because the ratio of horizontal length to $50 \mathrm{~m}$ decreases as relief increases, the ratios were transformed by assigning them positive scores between zero (minimum relief) and 5.0 (maximum relief) (Table 2).

The relationship between the horizontal length $/ 50 \mathrm{~m}$ ratio and the Relief Index is expressed by the equation:

$$
Y=10-10 X
$$

where $Y=$ Relief Index and $X=$ horizontal length $/ 50 \mathrm{~m}$

The Relief Index values for all stations are presented in Table 3

The relationship between fish standing crop biomass and habitat complexity (Relief Index) was determined by linear regression and covariance analysis.

An estimate of steady state biomass (standing crop) for reef fish on an unfished representative Hawaiian coral reef was determined using the ECOPATH model (see Table 3 and Fig. 1 in Polovina 1984) based on an analysis of the reef ecosystem at French Frigate Shoals Atoll (FFS) in the northwestern Hawaiian Islands. The mean annual wet weight biomass for reef fishes at FFS determined by the ECOPATH model is $23941 \mathrm{~kg} \mathrm{~km}^{-2}$. For application to high island ecosystems, this value was increased a factor of $2.7(1.92 \times 1.41)$. These conversion factors were derived as follows: $60 \%$ of the atoll at FFS is lagoonal habitat and this is $1 / 5$ as productive as reef habitat $[1 /(0.6 \times 0.2+0.4 \times 1.0)=1.92]$,

Table 2. Ratios of horizontal tape length to $50 \mathrm{~m}$, scores and description of bottom topography

\begin{tabular}{|ccl|}
\hline $\begin{array}{c}\mathrm{X} \text { (horiz. } \\
\text { length/50 } \mathrm{m})\end{array}$ & $\begin{array}{c}\text { Y (Relief } \\
\text { Index) }\end{array}$ & $\begin{array}{l}\text { Topographic } \\
\text { complexity }\end{array}$ \\
\hline 1.0 & 0 & Flat \\
0.9 & 1 & Low relief \\
0.8 & 2 & Low-moderate relief \\
0.7 & 3 & Moderate relief \\
0.6 & 4 & High-moderate relief \\
0.5 & 5 & High relief \\
\hline
\end{tabular}

Table 3. Relief Indices for all stations

\begin{tabular}{|lcc|}
\hline Station & Depth $(\mathrm{m})$ & Relief Index \\
\hline Waianae Outfall & 33 & 1.1 \\
Waianae Outfall Control & 33 & 1.1 \\
Waianae Outfall Pipeline & 15 & 3.5 \\
Waianae Pipe Control 1 & 15 & 1.5 \\
Waianae Pipe Control 2 & 15 & 2.25 \\
Kailua Outfall & 33 & 3.75 \\
Kailua Outfall Control & 33 & 1.0 \\
Kailua Pipeline & $12-15$ & 3.6 \\
Kailua Pipeline Control & 15 & 1.2 \\
Sandy Beach Outfall & $12-15$ & 1.8 \\
Sandy Beach Control & 15 & 2.0 \\
Haunama MLCD & 15 & 2.0 \\
Haunama Control & 15 & 2.0 \\
Honolua MLCD north & 15 & 2.25 \\
Honolua MLCD south & $10-15$ & 2.6 \\
Honolua Bay Control & $12-15$ & 1.4 \\
Manele Bay MLCD & $10-15$ & 2.5 \\
Lanai Control 1 & $10-15$ & 2.0 \\
Lanai Control 2 & $10-15$ & 2.75 \\
Molokini MLCD & 15 & 1.5 \\
Molokini Control & 16 & 2.5 \\
Kealakakua MLCD & $10-15$ & 3.2 \\
Kealakakua Control & $10-15$ & 2.5 \\
\hline
\end{tabular}

and, actual measures of net primary productivity at FFS were $6.1 \times 10 \mathrm{~kg} \mathrm{~km}{ }^{-2} \mathrm{yr}^{-1}$ (Atkinson \& Grigg 1984) versus $4.3 \times 10 \mathrm{~kg} \mathrm{~km}^{-2} \mathrm{yr}^{-1}$ for the ECOPATH model $(6.1 / 4.3=1,41)$. These conversions produced a theoretical estimate of wet weight standing crop biomass of $64640 \mathrm{~kg} \mathrm{~km}{ }^{-2}$ per transect or $64.6 \mathrm{~g} \mathrm{~m}^{-2}$ (see Fig. 5). This biomass is an estimate of the carrying capacity of an unfished representative high island reef ecosystem covering an area of $1000 \mathrm{~m}^{2}$. It is treated here as a 'standard of optimum performance' (no fishing, no pollution) against which the standing crops of reef fishes at all stations in the study were compared.

\section{RESULTS}

\section{Coral species richness and abundance}

Differences between the mean number of coral species present at outfall, pipeline or MLCD stations versus corresponding control stations were all small and statistically nonsignificant (Table $4: t$-test for difference between the means of Outfalls vs Controls, $\mathrm{p}=0.27$; Pipeline vs Controls, $\mathrm{p}=0.13 ;$ MLCDs vs Controls, $p=0.52$ ). In part, this is due to the small number of coral species which are abundant in the Hawaiian Islands. Also, the area covered by each transect $\left(7 \mathrm{~m}^{2}\right.$ total) was very small. Rare species would not be expected to occur in such small areas. For example, at Haunama Bay, the mean number of species of coral 
Table 4. Number of coral species at all stations; means and standard deviations

\begin{tabular}{|lcc|}
\hline Station & Treatment & Control \\
\hline Kailua Outfall & $3.33(0.58)$ & $4.00(0)$ \\
Waianae Outfall & $3.50(0.70)$ & $3.00(0)$ \\
Sandy Beach Outfall & $5.66(0.58)$ & $4.66(1.15)$ \\
Kailua Pipeline & $4.33(0.58)$ & $5.00(1.41)$ \\
Waianae Pipeline & $2.66(0.58)$ & $4.00(1.26)$ \\
Haunama Bay MLCD & $3.33(0.58)$ & $4.66(1.15)$ \\
Honolua Bay MLCD & $5.87(1.13)$ & $5.00(1.41)$ \\
Manele Bay MLCD & $5.66(0.58)$ & $5.00(1.14)$ \\
Molokini MLCD & $6.00(0)$ & $5.33(1.15)$ \\
Kealakakua Bay MLCD & $6.66(1.15)$ & $4.00(1.4)$ \\
a Outfall, pipeline and MLCD stations can be considered \\
treatments since they represent a situation which alters \\
existing environmental conditions \\
\hline
\end{tabular}

recorded on transects taken over the 2 yr study was only 3.3, however, qualitative surveys covering much larger areas at Haunama Bay have produced as many as 12 species (pers. obs.). Large areas can easily be surveyed qualitatively underwater in order to compile a presence/absence species list but quantitative surveys in which individual coral species cover is enumerated are much more time consuming. In spite of this limitation, the results of the study exhibit a consistent trend, i.e. the differences in coral species richness between all station comparisons are nonsignificant (Table 4, Fig. 1).

Looking closer at the outfall versus control stations, the mean number of coral species present at outfall stations (4.37) was slightly higher than the mean at control stations (4.0) although nonsignificant $(p=0.27$ ). Differences in coral abundance (cover) at these 2 sets of stations were also very small (Fig. 1). Therefore, it does not appear that the discharge of sewage effluents at these outfall sites has produced any negative impacts on coral communities. Consistent with this result was the absence of any particulate organic matter (POM) or sediment on the bottom around the outfalls during surveys. Neither was there any evidence of coral bleaching or unusual mortality of any species of coral, algae or invertebrate in the vicinity of the outfall diffusers.

The results of water quality analyses done in connection with this study are reported elsewhere (Parnell 1992). In summary, this part of the study showed that POM in the effluent at both Kailua and Waianae outfalls was elevated about 3 orders of magnitude above normal. POM dispersed very quickly and reached ambient or background levels in 10 min or less after discharge. This was also true for the dissolved nutrients in the effluent, $\mathrm{NH}_{4}{ }^{+}, \mathrm{PO}_{4}{ }^{3-}, \mathrm{NO}_{3}{ }^{-}, \mathrm{NO}_{2}, \mathrm{Si}$ and total coliform bacteria (Parnell 1992).
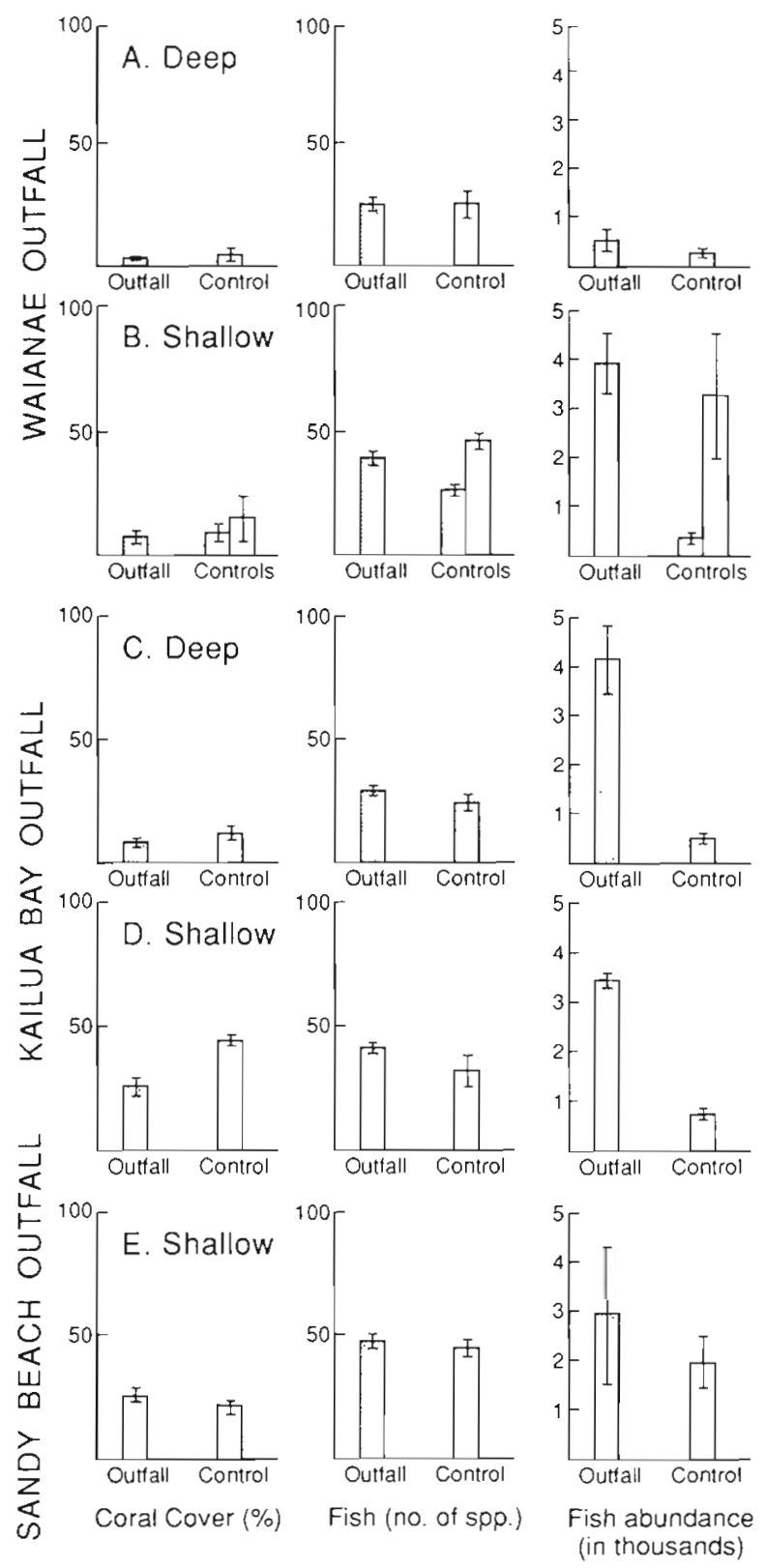

Fig. 1. Coral cover, number of fish species and fish abundance at outfall and control stations at Waianae, Kailua Bay and Sandy Beach, Oahu. Error bars indicate standard deviation

\section{Fish species richness and abundance}

In contrast to the lack of difference between coral species richness and abundance at outfall, pipeline and MLCD stations compared to corresponding control stations, patterns of fish diversity and abundance exhibited some rather marked differences between stations (Figs. 1 \& 2, Table 5). Fish species richness was not significantly different between the outfall and control stations $(p=0.47)$ or the pipeline and control stations 

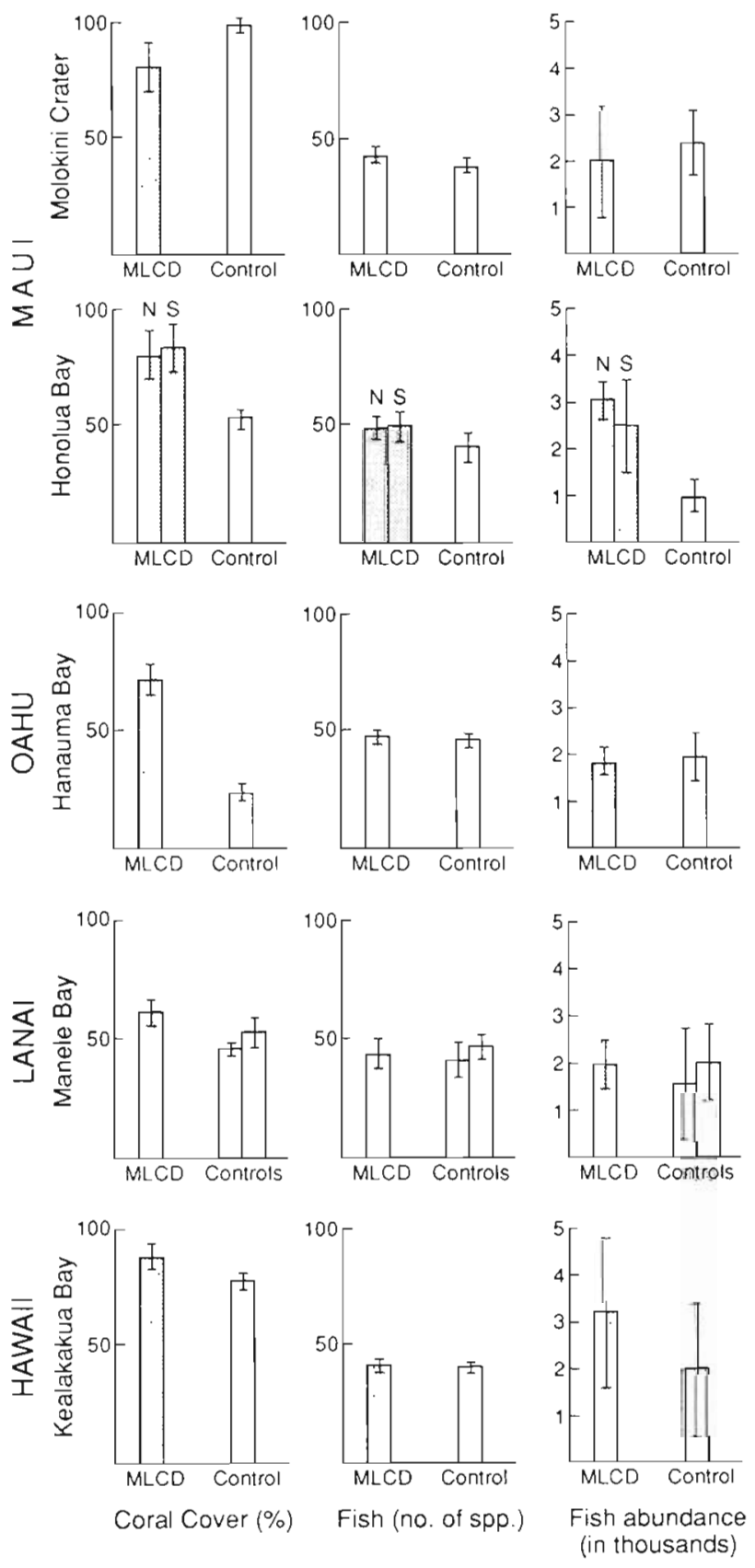

Fig. 2. Coral cover, number of fish species and fish abundance at all MLCDs and MLCD control stations. Error bars indicate standard deviation

$(p=0.15)$ but it did show a significant difference between MLCD and control stations ( $p=0.03$ ). The MLCD stations contained on average 4 species more fish than the MLCD control stations. The outfalls and pipelines do not appear to change fish species diversity while the protection from fishing (MLCDs) apparently does. Species which are absent or less abundant at the control stations not protected from fishing are those species which are frequently targeted by commercial and recreational fishermen. These include taape Lutjanus kasmira, kumu Parupeneus porphyreus, papio and ulua Caranx spp., hole hole Kuhlia sandvicensis, aweo-weo Priacanthus cruentatus and several species of parrot fish.

Large and significant differences in fish abundance were found between the outfall, pipeline and MLCD stations and their respective control sites (Figs. 1 \& 2, Table 5). Considering outfalls first, at the Kailua outfall, the average abundance of fish was 7.6 times greater than the Kailua deep water control. At the Waianae outfall, mean fish counts were 2.2 times higher that at the deep water control station, and, at the Sandy Beach outfall, 1.5 more fish (Fig. 3) were present than at the control site. The difference between mean fish abundance at outfall versus control sites was significant at the $p=0.03$ level.

In general, fish abundance estimates in MLCDs were also higher than at unprotected control sites $(p=0.02)$. This was particularly true at Honolua Bay on Maui and Kealakuaka Bay on Hawaii (Figs. 2 \& 4). The control or comparison sites for both of these MLCDs are fished at relatively heavy levels by both commercial and recreational fishermen. Approximately 15 fishing lines were found tangled on the bottom in the coral at the Kealakakua Bay control site.

Fish abundance was also higher at outfall pipeline stations in shallow water (ca $12 \mathrm{~m}$ ) relative to control sites. The difference in means between counts at pipeline vs control sites was significant at the $p=0.01$ level (see B \& D in Fig. 1). At Waianae, 2 control sites were investigated, one with a relief index of 1.5 and the other 2.25. The difference in means between these 2 control sites was also highly significant $(p<0.001$, Fig. 1B); the site with the higher relief index contained about 6 times more fish than the flatter reef.

The differences in fish abundance and biomass between outfall, pipeline, MLCD and control stations suggest that habitat complexity, fishing pressure and some characteristic of the sewage effluent are all important factors in controlling the abundance of fishes at the stations investigated in this study. In order to separate the effects of each of these factors, data were analyzed using regression and analysis of covariance. For these analyses, fish counts were converted to biomass as described in the 'Methods'. This was done in order to standardize the variance and allow comparisons (in units of biomass) to reef fish abundances elsewhere in the world. This also reduced differences between stations due to the presence or absence of new year class recruits. Further, it allowed comparison of fish abundance in the high Hawaiian Islands to French Frigate Shoals where the entire ecosystem has been modeled using biomass (ECOPATH model, Polovina 1984; also see 'Methods'). 
Table 5. Means and standard deviations of tish species richness (no. of species), abundance (counts) and biomass (kg) at all stations averaged over season

\begin{tabular}{|c|c|c|c|c|c|c|}
\hline Station & Species & Abundance & Biomass & Species & Abundance & Biomass \\
\hline & & - Outialls & & - & - Controls & \\
\hline Kailua & $30.0(2)$ & $4183(759)$ & $300(54)$ & $25.5(3.5)$ & $549(15)$ & $16.5(2.1)$ \\
\hline Waianae & $26.6(2.1)$ & $547(153)$ & $23(9.6)$ & $26.0(5.7)$ & $252(17)$ & $10.0(4.2)$ \\
\hline \multirow[t]{2}{*}{ Sandy Beach } & $48.3(3.1)$ & $3001(1311)$ & $156(93)$ & $46.3(2.1)$ & $1943(563)$ & $106.0(41)$ \\
\hline & & Pipelines & & & Controls & \\
\hline Kailuā & $41.0(2)$ & $3485(71)$ & $160(59)$ & $33.5(6.4)$ & $727(110)$ & $17.5(3.5)$ \\
\hline \multirow[t]{2}{*}{ Waianae } & $39.3(2.3)$ & $3970(757)$ & $118(54)$ & $35.6(12.3)$ & $1801(1810)$ & $117.0(122)$ \\
\hline & & MLCDs - & 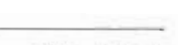 & & Controls & \\
\hline Haunama & $48.3(2.51)$ & $1793(446)$ & $77.6(23.1)$ & $46.3(2.1)$ & $1403(1193)$ & $106(40)$ \\
\hline Honolua & $49.7(5.5)$ & $2795(772)$ & $93.0(29.8)$ & $40.7(5.8)$ & $1019(311)$ & $24(13.2)$ \\
\hline Manele & $44.0(4.8)$ & $1961(691)$ & $79.5(30.2)$ & $45.6(5.9)$ & $1851(902)$ & $64(31.7)$ \\
\hline Molokini & $42.6(3.2)$ & $2043(1317)$ & $107.0(54.3)$ & $37.3(1.5)$ & $2410(789)$ & $101(29.8)$ \\
\hline Kealakakua & $41.3(1.2)$ & $3160(1.660)$ & $194.0\{86.1\}$ & $40.5(2.1)$ & 2016 (1392) & $47(4.2)$ \\
\hline
\end{tabular}

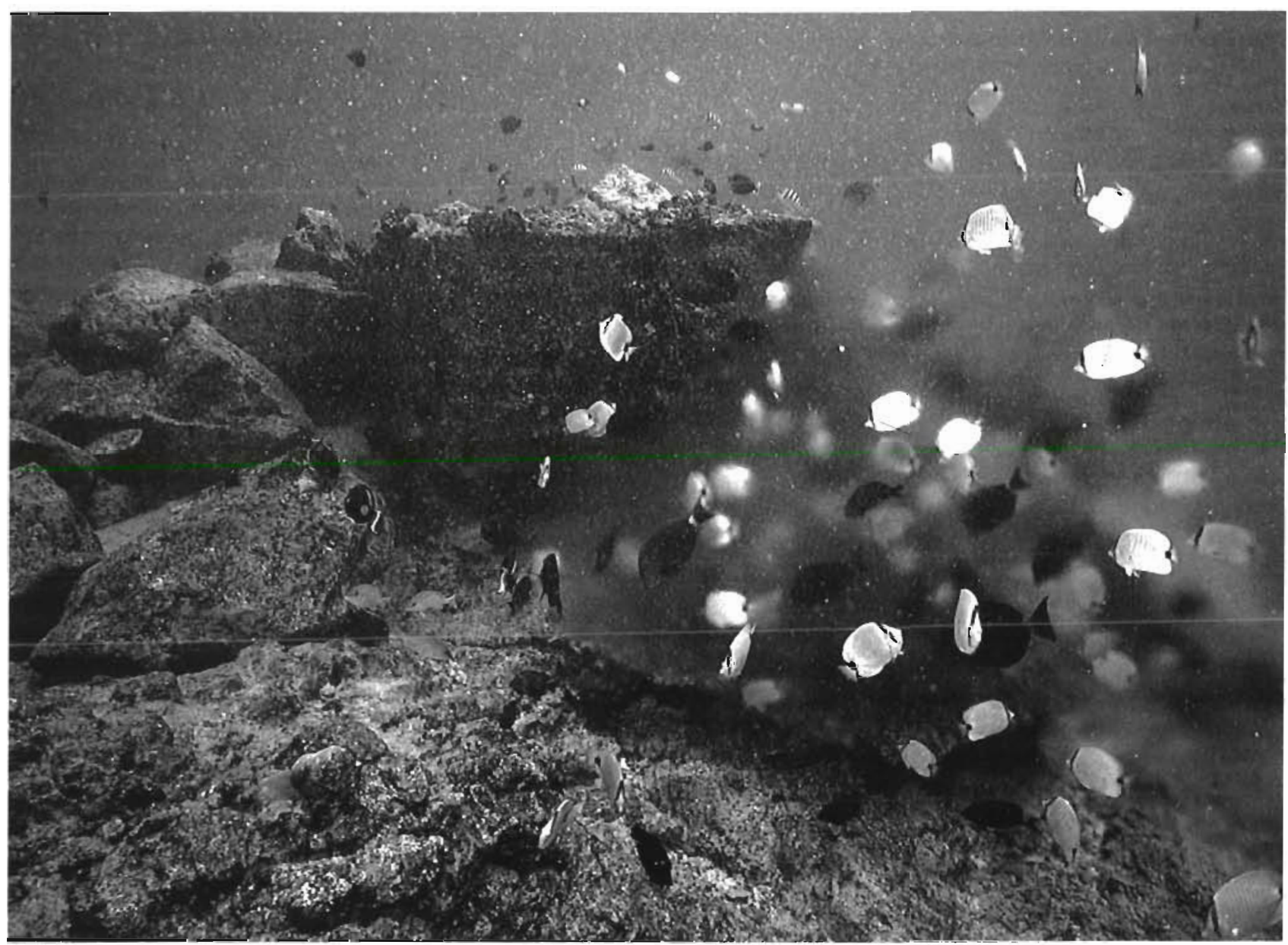

Fig. 3. Reef fish were more abundant around outfall stations compared to control areas and often were observed to aggregate within effluent plumes and forage on particulate organic matter 
In order to test the effect of bottom relief on fish biomass alone, index values of habitat complexity were regressed against the natural log of mean biomass estimates for all fish present at all stations on all survey dates over the $2 \mathrm{yr}$ study. This regression analysis was significant at the 0.01 level of probability and produced the equation $Y$ (ln biomass) = $2.37+0.83 X$ (habitat complexity). The $\mathrm{R}^{2}$ was 0.51 , indicating that about half of the variance is due to habitat complexity alone. The analysis of covariance of the effects of habitat complexity, outfalls and fishing pressure on biomass produced an $\mathrm{R}^{2}$ value of 0.60 , suggesting that an additional $9 \%$ of variance is due to the exposure of some stations to fishing pressure or sewage discharge. Indeed, the analysis of covariance showed that the differential effects of exposure of some stations to sewage discharge and fishing pressure were significant at a probability of $<0.01$ (Fig. 5). Mean fish biomass of all stations exposed to sewage discharge was $124.2 \mathrm{~g} \mathrm{~m}^{-2}$ (26.3 SE) versus $67.4 \mathrm{~g} \mathrm{~m}^{-2}(5.15 \mathrm{SE})$ for unexposed stations, a difference of $56.8 \mathrm{~g} \mathrm{~m}^{-2}$. The difference in means between stations protected from fishing versus those exposed to fishing was $45 \mathrm{~g} \mathrm{~m}^{-2}(1.16 .7-$ $71.3 \mathrm{~g} \mathrm{~m}^{-2}$. The remaining $40 \%$ of the variance in biomass can be attributed to other factors including counting errors, length/weight conversion errors, differences in biomass caused by changes in swell conditions and water visibility and other unknown sources of variability.

\section{DISCUSSION}

Coral species and fish species richness are both weak indicators of the effects of sewage discharge and differential fishing pressure in Hawaii. For corals, this is not surprising, since the Hawaiian Archipelago is extremely isolated from the source of coral species in the IndoWest Pacific (IWP), and less than $10 \%$ of the IWP species exist in Hawaii (Grigg 1983, 1988). The small area covered by each transect $\left(7 \mathrm{~m}^{2}\right)$ also contributed to this result, since rare species would not likely be encountered. Transect measures were dominated by a few very common species such as Porites lobata, P. compressa, Pocillopora meandrina and 2 species of Montipora ( $M$. patula and $M$. verrucosa). For fish, the lack of very large differences in species composition is also not surprising in view of the findings of Hobson (1984) who reported that fish species composition is fairly constant in similar habitats throughout the Hawaiian Archipelago. It is noteworthy that neither the discharge of primary or secondary treated sewage had any significant effect on coral or fish species composition.

In sharp contrast to coral and fish species composition, fish abundance (numbers and biomass) was a strong indicator of differences between stations. The regression of the natural log of fish biomass against habitat complexity showed that bottom topographic relief accounts for over half $(51 \%)$ of the variability. The analysis of covariance showed that another $9 \%$ of the variance could be attributed to the effects of

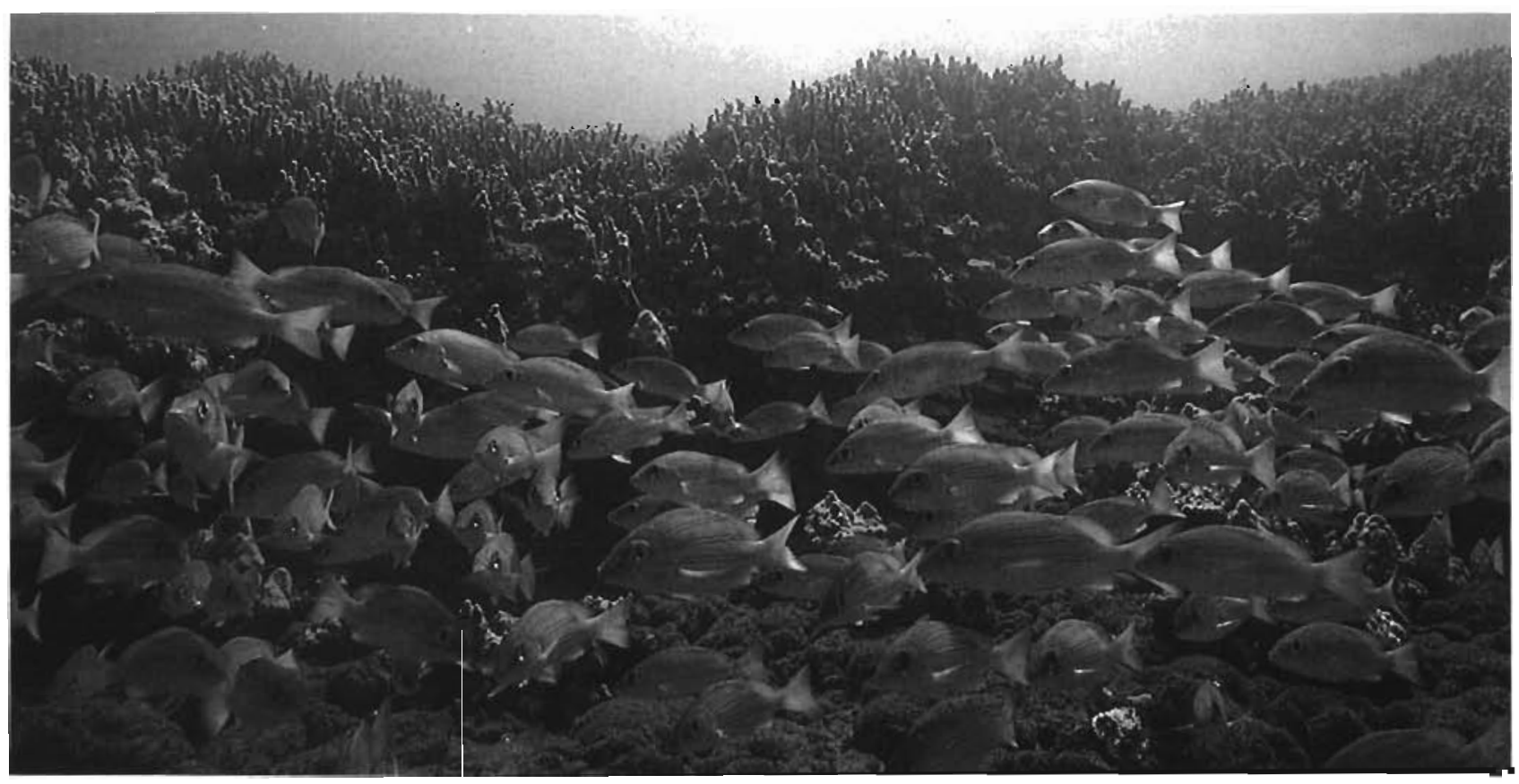

Fig. 4. Standing crops of fish were higher in MLCDs relative to control areas exposed to heavy fishing pressure. Here, a large school of taape Lutjanus kasmira has aggregated along the reef in Honolua Bay, Maui 

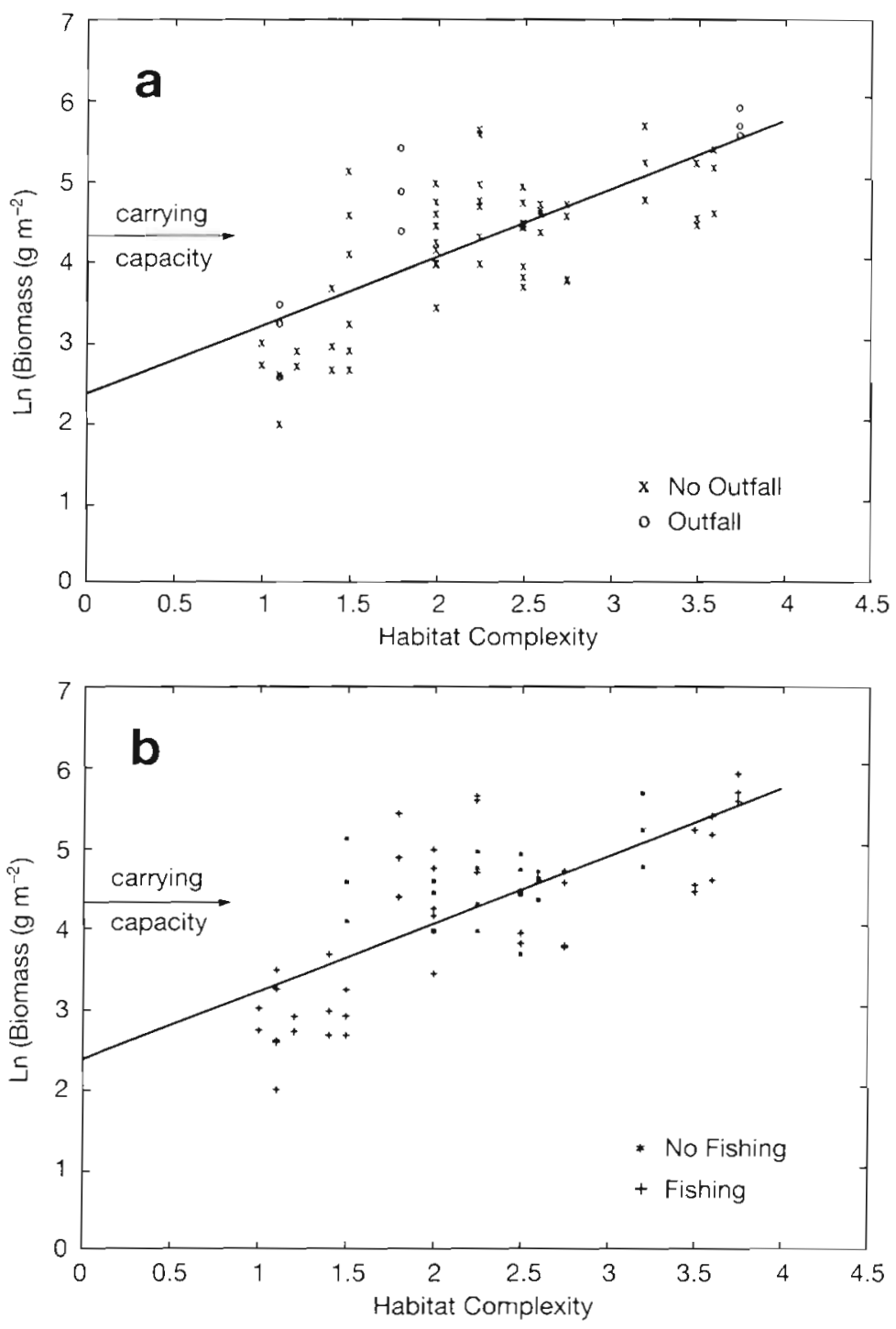

Fig. 5. $\log _{e}$ biomass of fish surveyed at all stations plotted as a function of habitat complexity. (A) Stations coded as either outfall or non-outfall. (B) Stations coded as either exposed to or protected from fishing pressure. Maximum theoretical carrying capacity $\left(65 \mathrm{~g} \mathrm{~m}^{-2}\right)$ indicated on each figure

tor) are plankton or particulate organic matter feeders and were seen foraging on POM in the effluent in the water column around the outfall. At the Sandy Beach outfall, over $60 \%$ of the fish were planktivores or suspended-particle feeders (Fig. 3).

At the outfalls studied, no negative impacts were produced by the discharge of either primary or secondary treated effluent into the ocean. Corals, algae and invertebrates were virtually unaffected.

Fishing pressure produced a negative and statistically significant effect. It accounted for a difference of about $45 \mathrm{~g} \mathrm{~m}^{-2}$ of fish biomass between stations protected (MLCDs) versus those unprotected from fishing. This result supports the qualitative impressions of commercial and recreational fishermen who consider overfishing to be a major cause of the long-term statewide decline in fish abundance (Harmon \& Katekaru 1988). Another indication of the effect of fishing pressure was the behavior of reef fishes. Many species (kumu, ulua, parrotfish, squirrelfish, holehole, aweo-weo etc.) which normally dart away from human observers in areas heavily fished, are remarkably tame in the MLCDs. This is particularly true in Haunama Bay, Kealakakua Bay, Honolua Bay and Molokini Crater, where they have become a popular tourist attraction.

Perhaps the most remarkable finding of this study is the high percent of stations (MLCDs and outfall stations but some control stations as well) that support levels of fish standing crop above the estimated carrying capacity of the reef ecosystem based on the ECOPATH model (see 'Methods' and Fig. 5). It is possible that the modified ECOPATH estimate of $65 \mathrm{~g}$ $\mathrm{m}^{-2}$ is too low, however, this is not likely in view of comparable estimates for the stand-

sewage discharge and fishing pressure. The effect of all 3 variables, habitat complexity, exposure to sewage and fishing pressure on fish biomass, was significant at the $p<0.01$ level. The effect of habitat complexity was particularly strong (Fig 5). The highest levels of biomass were recorded at those stations with the highest relief indices, such as the outfall diffusers and pipeline stations at Kailua, the pipeline station at Waianae and the Kealakakua Bay MLCD station.

The positive effect of sewage discharge may in part be a result of POM (food subsidies) in the effluent. Three of the 4 dominant species of fish at the Kailua outfall (mamao Abudefduf abdominalis, butterfly fish Chaetodon miliaris and the damselfish Chromis vera- ing crop of coral reef fishes in many reef ecosystems elsewhere in Hawail and the worid $\left(36 \mathrm{~g} \mathrm{~m}^{-2}\right.$ average of 9 areas in Hawaii, Brock 1954; $49 \mathrm{~g} \mathrm{~m}^{-2}$ for Bermuda, Bardach 1958; $45 \mathrm{~g} \mathrm{~m}^{-2}$ at Enewetak, Odum \& Odum 1955; and $27 \mathrm{~g} \mathrm{~m}^{-2}$ average for Puerto Rico, Fast 1974). A more likely explanation is that the modified ECOPATH estimate of carrying capacity is reasonable and the higher values encountered in this study are due to the aggregation of fishes. This may especially apply to outfall stations where pipeline caprock provides high relief, interstitial space and therefore shelter for reef fishes. Outfalls produce a large amount of particulate matter, which (as discussed above) may be a food subsidy to some fishes (Fig. 3). 
Fish aggregation in areas of high relief is a behavior consistently observed by Hawaiian fishermen. A name for such areas, koa (meaning fish house), exists in the Hawaiian language. Presumably the fish inhabiting such 'houses' must forage over much larger areas (probably at night) to meet their metabolic needs. Randall (1963) found this to be true on a Caribbean patch reef.

Areas characterized by high relief and interstitial space are similar to artificial reefs in terms of their ability to aggregate fish. As with artificial reefs, koas would be expected to increase the catchibility of reef fishes (Stone et al. 1979, Brock \& Norris 1989, Meier et al. 1989, Polovina 1991). Aggregation of reef fish in koas may partially explain why coral reef fishes are so vulnerable to overexploitation (Grigg et al. 1984, Meier et al. 1989, Polovina 1991). Catchability would be expected to increase in such areas and many year classes of fish may be exposed to fishing at the same place and time. It has been suggested that prey stocks are naturally exploited at a maximum levels by predators so that even limited fishing pressure can cause rapid decline of stocks (Pauley 1979). Hence, the resource can be diminished rapidly.

One corollary for the purpose of conservation and management might be to protect high relief areas, koas or even artificial reefs from fishing. This is exactly opposite to most government policies concerning artificial reefs (Stone 1985, Seaman et al. 1989, Polovina 1991). The protection of koas from fishing might be particularly important in areas like Hawaii where nonconsumptive recreational uses such as snorkelling and SCUBA charters for observation and underwater photography are of much higher economic value than revenues produced by the sale of caught fish. In Hawaii, this approach has been applied successfully by selecting koas for MLCDs in which most forms of fishing are prohibited.

Acknowledgements. I thank Ed Parnell, a graduate student at the University of Hawaii, who conducted the research on water quality of the sewage discharges in this study. This topic formed the subject of Ed Parnell's Master's thesis and will be published separately. I also want to thank Bret Baxley and Roger Pfeffer for their hard work and competence in the field collecting underwater data. Jeff Polovina and Zhou Xiaomei provided invaluable assistance with the statistical analysis and computer programming. This research was supported by the State of Hawaii, Department of Land and Natural Resources, and I thank Bill Paty, Chairman of the Board of Land and Natural Resources and Henry Sakuda, Director of the Division of Aquatic Resources for their support. The study was part of the Main Hawaiian Island Marine Resource Investigations (MHI-MRI) of the State of Hawail coordinated by Kimberly Smith.

\section{LITERATURE CITED}

Anderson, G. R. V., Ehrlich, A. H., Ehrich, P. R., Roughgarden, J. D., Russel, B. C., Talbot, F. H. (1981). The community structure of coral reef fishes. Am. Nat. 117: 476-495

Atkinson, M. J., Grigg, R. W. (1984). Model of a coral reef ecosystem. 1I. Gross and net benthic primary production at French Frigate Shoals, Hawaii. Coral Reefs 3: 13-22

Bardach, J. E. (1958). On the movements of certain Bermuda reef fishes. Ecology 39: 139-146

Brock, R. E., Norris, J. E. (1989). An analysis of the efficacy of four artificial reef designs in tropical waters. Bull mar. Sci. 44: $934-941$

Brock, V E. (1954). A preliminary report on a method of estimating reef fish populations. J. Wildl Mgmt 18 : $297-308$

Evans, C. (ed.) (1974). Pearl Harbor biological survey. Tech. Rep. Naval Undersea Center 1128: (p. 2.1,16-17 and 2819)

Fast, D. E. (1974). Comparative studies of fish species and their populations on artificial and natural reefs off southwest Puerto Rico. M.Sc. thesis, University of Puerto Rico

Gladfelter, W. B., Gladfelter, E. H. (1978). Fish community structure as a function of habitat structure on West Indian patch reefs. Rev. trop. Biol. 26: 65-84

Grigg, R. W. (1983). Community structure, succession and development of coral reefs in Hawaii. Mar. Ecol. Prog. Ser 11: $1-14$

Grigg. R. W. (1988). Paleoceanography of coral reefs in the Hawaiian-Emperor chain. Science 240: 1737-1743

Grigg, R. W., Maragos, J. E. (1974). Recolonization of hermatypic corals on submerged lava flows in Hawaii. Ecology 55: $387-395$

Gngg, R. W., Polovina, J. J., Atkinson, M. J. (1984). Model of a coral reef ecosystem. IIl. Resource limitation, community regulation, fisheries yield and resource management. Coral Reefs 3: 23-27

Harmon, R. F., Katekaru, A. Z. (1988). Hawaii commercial fishing survey: Summary of results. State of Hawail, DLNR, HDAR Rep. Honolulu

Hobson, E. S. (1984). The structure of reef fish communities in the Hawaiian Archipelago. Proc. NWHI Symp., University of Hawaii Sea Grant MR 84-01. Honolulu, p. 57-70

Meier, M. H., Buckleg, R., Polovina, J. J. (1989). A debate on responsible artificial reef development. Bull. mar. Sci. 44: $1051-1057$

Nelson, W. G., Bailey-Broch, J. H., Cook, W. J., Kay, E. A. (1991). Benthic faunal sampling adjacent to Barbers Point ocean outfall, Oahu, Hawaii, Feb. 1990. Water Resources Research Center Spec. Rept. 0444-01-91, University of Hawaii, Honolulu

Odum, H. T., Odum, E. P. (1955). Trophic structure and productivity of a windward coral reef community on Eniwetok Atoll. Ecol. Monogr. 25: 291-320

Parnell, E. (1992). Impacts to phytoplankton and water quality of Hawaiian coastal waters by primary and secondary sewage outfalls. M.Sc thesis, Univ. of Hawaii

Pauley, D. (1979). Theory and management of tropical multispecies stocks; a review with emphasis on the southeast Asian demersal fisheries. ICLARM Stud. Rev. 1: 1-35

Polovina, J. J. (1984). Model of a coral reef ecosystem. I. The ECOPATH Model and its application to French Frigate Shoals. Coral Reefs 3: 1-11

Polovina, J. J. (1991). Fisheries applications and biological impacts of artificial habitats. In: Seaman, W., Sprague, L. M. (ed.) Artificial habitats for marine and freshwater fisheries. Academic Press, New York 
Randall, J. E. (1963). An analysis of the fish populations of artificial and natural reefs in the Virgin Islands. Caribb. J. Sci. 3: 31-47

Ricker, W. E. (1975). Computation and interpretation of biological statistics of fish populations. Bull. 191, Dept Environ. Fish. Mar. Serv., Ottawa, p. 207

Russo, A. R. (1982). Temporal changes in fish community structure near a sewage ocean outfall, Mokapu, Oahu, Hawaii. Mar. environ Res. 6: 83-98

Russo, A. R., Dollar, S. J., Kay, E. A. (1981). Benthic ecosystems and fish populations off the Mokapu outfall; a third post installation study. Tech. Rept. 65, Water Resources Research Center, University of Hawaii, Honolulu

Russo, A. R., Kay, E. A., Bailey-Brock, J. H., Cook, W. J. (1988). Benthic faunal sampling off the Sand Island ocean outfall,

This article was submitted to the editor
Oahu, Hawaii. Spec. Rep. 06-12-88, Water Resources Research Center, University of Hawaii, Honolulu

Seaman, W., Buckley, R. M., Polovina, J. J. (1989). Advances in knowledge and priorities for research, technology and management related to artificial aquatic habitats. Bull. mar. Sci. 44: $527-532$

Shomura, R. S. (1987). Hawaii's marine fishery resources; yesterday (1900) and today (1986). Admin. Rep. H-87 21, Natn. mar. Fish. Serv., NOAA Honolulu Lab.

Stone, R. B. (1985). National artificial reef plan. NOAA Tech Memo, Natn mar. Fish. Serv., NOAA-TM-NMFS-OF 6

Stone, R. B., Pratt, H. L., Parker, R. D. Jr, Davis, G. E. (1979). A comparison of fish populations on an artificial and natural reef in the Florida Keys. Mar. Fish. Rev. 41: 1-11

Sun, M. (1989). Mud-slinging over sewage technology. Science 246: $440-443$

Manuscript first received: October 22, 1992

Revised version accepted: September 16, 1993 